I. Yakovenko, Yu. Vasilevskyi, Y. Basova, Kharkiv, Ukraine, Milan Edl, Plzen, Czech Republic

\title{
TECHNOLOGICAL PROVISION OF THE ACCURACY FOR THE THREAD FORM OF ROD PUMPS
}

\begin{abstract}
Aspects of thread manufacturing used in downhole rod pumps are considered. Technological defects of distortion of lateral surfaces of a thread profile arising in the course of processing on CNC machines are described, and the factors which most influence formation of these defects are established. The influence of profile defects on the reliability of the threaded connection during the operation of rod pumps is analyzed, as well as the research on the dynamics and oscillations of machine systems is analyzed. With the performed analysis the mathematical model of real technological system in the course of machining process is created and investigated. The main technological factors that have the greatest influence on the occurrence of error in the shape of the thread surface are identified. With the help of software for analysis of dynamic systems, the necessarily calculations were performed and the behavior of the dynamic system in the process of forming the thread profile was considered. Based on the analysis of the obtained results, a system for managing the parameters of the technological process of threading and technological solutions formulated. The introduction of which had a positive impact on the stability of the machining process and reduce the frequency of the above defect.
\end{abstract}

Keywords: threaded connection; thread profile; technological system; cutting mode; oscillations; amplitude; mathematical modeling.

Introduction. There are different types of rod pumps, which differ in the layout and design of the fastening system in the downhole, the design of certain components. The pump is a device with a length of more than ten diameters, the structure of which includes working, basing and connecting elements. Movable units are made with precise fits. The general design of the downhole pump consists of tubular parts connected by threads. That is, each pump part has at least two threaded surfaces. Rod pumps use different types of threaded connections, which differ in the type of profile, and generating, and technological requirements. The accuracy of the dimensions of the various threads is regulated by the relevant standards, which contain formulas for calculating the tolerance fields and/or a number of marginal deviations for individual dimensions and surface shapes [1,2].

Formulation of the problem. When machining threads with CNC lathes, a defect appears from time to time, which is a significant deterioration in the roughness of the side surfaces of the thread. The appearance of large notches, cyclically located along the turn of the thread is seen. Figures 1 and 2 show examples of parts with this defect on the internal thread. As can be seen in the figures, one part has more notches at the end of the threaded area (Fig. 1), and the other almost along its entire length (Fig. 2).

(C) I. Yakovenko, Yu. Vasilevskyi, Y. Basova, Milan Edl, 2021 


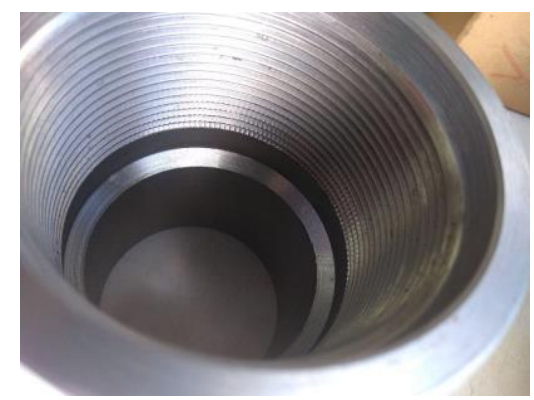

Figure 1 - Part with notches on the thread

All performed threads are machined on CNC lathes of different brands and year of manufacture, using turning cutters with replaceable plates. Plates with a full profile, which select the surface of the thread top on the last passes are also used, as well as general purpose ones, which are more universal.

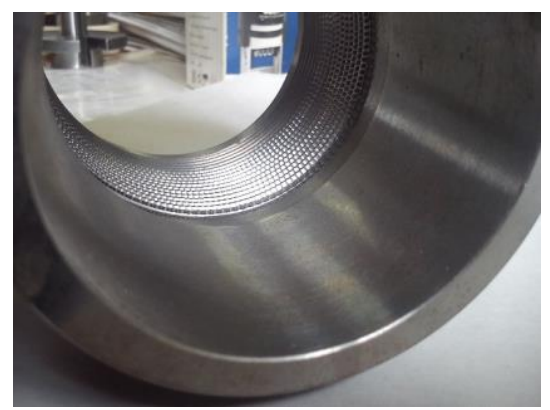

Figure 2 - Part with notches on the thread along its entire length

Cutting modes are selected according to the recommendations of the tool manufacturer, other standards and are adjusted depending on the conditions of the installment.

The appearance of the described defect is unsystematic. It takes place when making parts of different designs, the use of material from different batches, processing on different machines, different tools. But we can say that more often its appearance is observed while:

- processing of internal and conical threads,

- processing of large diameter threads,

- large departure of the processed surface. 
Uncontrolled excessive reduction of surface roughness parameters and accuracy of the thread profile shape has significant negative effects in the process of further pumps functioning:

- stress concentration - areas with a small radius of curvature serve as a focus of local concentrations of mechanical stress and provoke the emergence and development of microcracks;

- violation of the tightness of the thread due to uneven load distribution on the side surfaces of the profile and, including at the macro level due to deviations in the contact density;

- undesirable deviation in geometry of the location of the connection parts;

- negative impact on the quality of galvanic coatings - insufficient uniformity and adhesion leads to local destruction of the protective layer, which contributes to unpredictable corrosion;

- provoking more intensive corrosion wear of products due to accumulation in the irregularities of aggressive substances.

The appearance probability of the abovementioned problems indicates that the considered production defect is unacceptable. In practice, in case the rejected parts cannot be corrected by elaborating the thread to a satisfactory quality, these parts are rejected and are not allowed to be used in the product. To minimize such cases, the technology of manufacturing parts must ensure the stable performance of threading operations on a given equipment with maintained quality.

The purpose of this article is to develop a mathematical model of the dynamics of forming the surface of thread profile on lathes based on the identification and study of factors that determine the errors of the shape of the threaded surface profile, as well as control the parameters of thread formation to ensure stable quality of the process.

The deviation of geometric shapes from the theoretically given ones is caused by the circumstances inherent in the method of threading and arises as a result of the manifestation of a number of technological reasons [3]. For the non-systemic nature of shape errors, the most important factors are: unsatisfying mechanical properties of the workpiece material; workpiece locating errors; inaccuracies in the adjustment of all technological equipment and, as a consequence, dynamic phenomena of the cutting process, such as vibrations. When considering the conditions of vibration, it is necessary to make allowance for the rigidity of the entire processing system. And this: the lathe machine itself, the foundation under the machine, the device for different turning conditions, the tool, the part itself and the processing modes (Machine-Tool-Workpiece system or MTW) [4]. The most common type of vibration when working on metal-cutting machines is selfoscillation [5,6]. Self-oscillating or «autoexcitation» is a process in which nonextinguishing oscillations can be excited due to an energy source that does not have oscillatory properties. Intense self-oscillations of the tool occur mainly in the 
direction of the tangential component of the cutting force, where the rigidity of the cutter system is the lowest. They occur under the influence of friction forces on the back surfaces of the tool [7]. Prof. A. I. Kashirin and his followers consider this reason, along with the change of friction forces in the process of machining and wear of the tool, to be one of the main factors supporting self-oscillations [8]. Moreover, I. S. Amosov showed that the role of changes in the cross section of the cut during self-oscillations can be estimated at $85 \%$, and the role of all other causes only in $15 \%$ [9]. These studies are mostly general in nature and do not take into account modern technological systems and their capabilities.

In [10] the issues of intensity of self-oscillations at change of effort due to intermittent cutting process and influence of oscillations on shape errors during processing by cutting tool are considered, and conditions of excitation of parametric resonances, and also their intensity at boring of intermittent surfaces are studied. The discontinuity of the bored surface is described by the piecewise constant functions $\Phi(t)$. The calculations according to the proposed model are in good agreement with the experimental data when varying the cutting modes. Studies of the Provincial Key Laboratory for Green Cutting Technology and Lanzhou Institute of Technology, Lanzhou, China [11] are devoted to the mutual influence of cutting process parameters and equipment condition on the occurrence of vibrations and their intensity during machining on CNC machines. In the research [12] the issues of damping of self-oscillations during machining with a cutting tool due to variation of the cutting depth parameter are considered.

However, all the considered works take into account the specific processing conditions and MTW system, which differ from the existing ones for the studied problem, and the use of these models requires reliable and complete information about the dynamic state of the mechanical cutting system. The analysis of the considered sources allows to use to some extent the techniques offered by authors for development of dynamic model of thread cutting process, its further research and development of recommendations for production.

The main elements of the MTW dynamic system, interacting with each other, in the study of its characteristics are hysteretic damping system (springing system) the working processes of friction, cutting and processes occurring in the engines.

Mathematical modeling is based on solving the Lagrange equation (1) for individual coordinate directions:

$$
\frac{\mathrm{d}}{\mathrm{dt}}\left(\frac{\mathrm{dT}}{\mathrm{dx}_{\mathrm{i}}}\right)-\frac{\mathrm{dT}}{\mathrm{dx}_{\mathrm{i}}}=-\frac{\mathrm{d} \Pi}{\mathrm{dx}_{\mathrm{i}}}-\frac{\mathrm{dR}}{\mathrm{d \dot {x } _ { \mathrm { i } }}}+\Sigma \mathrm{Q}_{\mathrm{i}}
$$

where $\mathrm{T}$ - the kinetic energy,

$\Pi$ - potential energy,

$\mathrm{R}$ - the dissipative function,

$\mathrm{Q}_{\mathrm{i}}-$ external forces, 
$\mathrm{x}_{\mathrm{i}}-$ coordinates of displacements.

A dynamic machining system can be represented by a system with one degree of freedom. Figure 3 shows the surface of the part fixed in the chuck of the lathe, and the cutter in the carriage, which is set to turning with a depth of $\mathrm{t}, \mathrm{mm}$. The carriage is connected to the frame by stiffness $\mathrm{j}, \mathrm{N} / \mathrm{m}$ and damping coefficient $\mathrm{b}$, $\mathrm{Kg} / \mathrm{s}$.

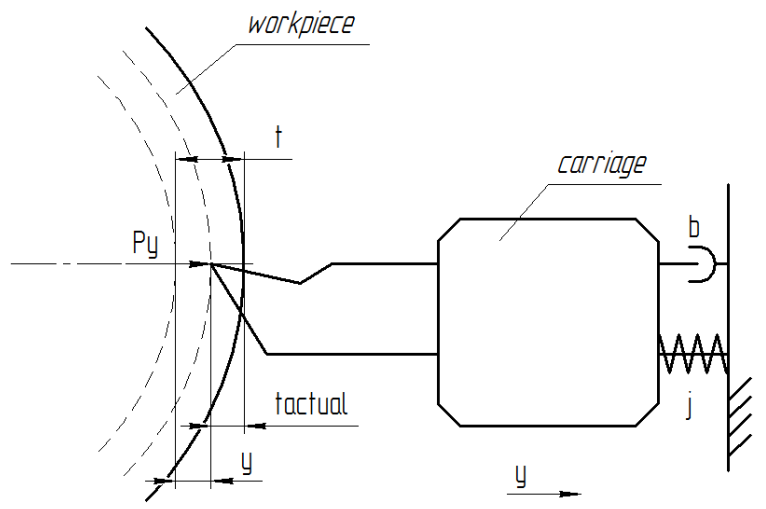

Figure 3 - Scheme of the process of longitudinal turning in the plane perpendicular to the axis of the part

When set to a given depth of cut (t) turning process provides a cutting force (P), which causes deformation of MTW system (y), which in turn affects the actual position of the cutter edge. This closed-loop system can be described by the following block diagram (Fig. 4):

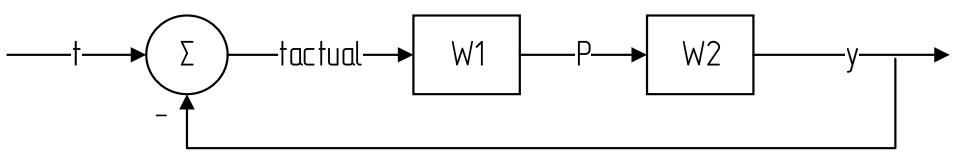

Figure 4 - Block diagram of the turning process with one degree of freedom

For a single coordinate it can be expressed by:

$$
\mathrm{W} 1=\mathrm{K}=\frac{\mathrm{P}}{\mathrm{t}^{\prime}}
$$

assuming that at the initial moment of time $\mathrm{P}, \mathrm{t}, \mathrm{K}$ are constants; 


$$
\mathrm{W} 2=\frac{1}{\mathrm{~m} \cdot \mathrm{s}^{2}+\mathrm{b} \cdot \mathrm{s}+\mathrm{j}}
$$

based on the equation of forces (linearization of the Lagrange equation).

Then the total transfer function of this system will be:

$$
\mathrm{W}=\frac{\mathrm{W} 1 \cdot \mathrm{W} 2}{1+\mathrm{W} 1 \cdot \mathrm{W} 2}=\frac{\mathrm{K}}{\mathrm{m} \cdot \mathrm{s}^{2}+\mathrm{b} \cdot \mathrm{s}+(\mathrm{j}+\mathrm{K})^{\prime}},
$$

where $\mathrm{m}, \mathrm{b}, \mathrm{j}$ - dynamic characteristics of the system, adopted on the basis of experimental studies for a specific MTW system,

$\mathrm{K}$ - the coefficient of proportionality of the cutting force, which reflects the influence of the turning depth on the resulting force and is calculated by the cutting modes, $\mathrm{s}$ - the complex variable of Laplace transformation.

For the proposed dynamic system as controlled parameters, it is advisable to consider cutting modes (only depth and cutting speed, because it is not possible to vary the feed when cutting threads), as well as the length of tool and workpiece as elements that affect the rigidity of the system. The stiffness of other elements of the MTW system was established experimentally, and in the proposed model is taken into account as a constant. To control other characteristics related to the rigidity of the equipment (design of the device and the machine) is also impractical in this case, as it requires additional costs for equipment upgrades, in addition, the equipment is used not only for machining threaded surfaces.

Simulation of process dynamics is performed using special software. Figure 5 shows an example of a simulated system, which is given by the block method (top), as well as using a special block "transfer function" (bottom). The second option is more convenient, although it requires additional calculations to determine the coefficients of the transfer function, which can be performed automatically in Excel along with the variation of parameters.

Multiple simulations of the threaded surface forming with specific geometric parameters with a step of $2 \mathrm{~mm}$ and a length of $40 \mathrm{~mm}$ was carried out.. In the simulation process, the following parameters were varied separately: cutting depth $t$, which depends on the number of passes of thread formation (and its dependent cutting force $\mathrm{P}$ ), cutting speed $\mathrm{v}$, system rigidity $\mathrm{j}$, which was set experimentally. The values of all other parameters were fixed as constants. All parameter values varied within the allowable ranges. The values of other parameters were constant and equal to the previously accepted.

The cut depth (number of passes) varied from $0.236 \mathrm{~mm}$ to $0.071 \mathrm{~mm}$. The average of the values of the position deviation of the cutter from a set level was $0.0656 \mathrm{~mm}$, and the average of the maximum position deviatons of the cutter from the steady state was $0.121 \mathrm{~mm}$. 
When changing the cutting speed (turning speed) in the range from $25 \mathrm{~m} / \mathrm{min}$ to $95 \mathrm{~m} / \mathrm{min}$, the average of the values of deviations of the cutter position from the set level was $0.0805 \mathrm{~mm}$, and the average of the maximum deviations of the cutter position from the steady state was $0.1498 \mathrm{~mm}$.

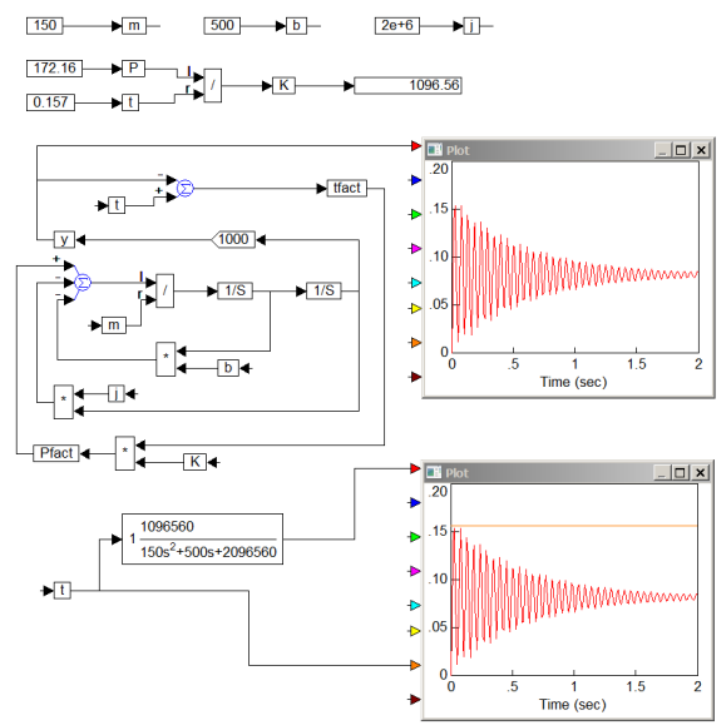

Figure 5 - Modeling of a dynamic system

The rigidity of the system varied from $1 \cdot 10^{6} \mathrm{~N} / \mathrm{m}$ to $1.9 \cdot 10^{6} \mathrm{~N} / \mathrm{m}$. When changing this parameter, the average of the values of deviations of the cutter position from the set level was $0.0688 \mathrm{~mm}$, and the average of the maximum deviations of the cutter position from the steady state was $0.1225 \mathrm{~mm}$.

As shown by the results of the analysis of the proposed models, the position of the cutting surface of the tool has not just a fixed position error, but is in an oscillating state. Moreover, this condition has a significant amplitude during surface cutting, and also has a clear relationship with the varied parameters.

For a more detailed assessment of the impact of the considered parameters, the calculations were performed, which establish how the change of each parameter is reflected in the change of the initial value. The considered parameters have different degree of influence on the modeled system. For example, a small relative change in the cutting depth parameter causes a larger relative change in amplitude than the same or even a larger relative change in the cutting speed parameter. 
This allowed to develop a software for managing technological parameters in the processing of threaded surfaces. These calculations are valid only for the considered specific processing system and the formed model of constant values of parameters which are established experimentally, and ranges of the varied parameters.

The calculation results, which were obtained on the basis of the proposed model, were checked during the processing of specific threaded surfaces of rod pump parts. The form errors in this case were avoided, which shows the adequacy of the model and the software.

Based on the evaluation of the obtained data and analysis of the simulation results, general technological measures are offered to improve the thread cutting process for specific geometrical parameters and shapes of threaded surfaces used in the manufacture of rod pumps (use of lubricants, timely control, sharpening and changing of cutting tools for ensuring the energy characteristics of the process in a given range, proper tightening of equipment connections, avoidance of imbalance of movable joints, etc.)

The proposed general measures are fully in line with the abovementioned recommendations.

\section{Conclusions:}

1. Based on the analysis of the defect nature, the causes and factors that affect the appearance of defects in the side profile of the threaded surface of the rod pumps parts are identified. The quantitative nature of the occurrence of springing deformations in the MTW system during machining was also established, which allowed to create a dynamic model of the thread machining process.

2. The proposed model allows to determine the technological parameters of the operation (cutting speed and depth, tool departure parameters) for a specific thread profile with specific geometric parameters (diameter, pitch, length, profile), which will provide the required accuracy of the threaded surface shape. The software block of models allows to define processing parameters from the point of view of optimization of two factors: maintenance of stable process of cutting without return of self-oscillations and maintenance of the maximum productivity (minimum time of forming of a carving surface). The proposed model allows to use it to determine the parameters of operations of processing of threaded surfaces by cutters on similar equipment.

References: 1. TU U 29.1-14331730-001: 2007. Nasosy skvazhinnyye shtangovyye i opory zamkovyye k nim. Tekhnicheskiye Usloviya - Vved. 25.03.2008. 2. Yakovenko I.Ye., Vasilevskiy Yu. Povysheniye tochnosti profilya rez'by pri obrabotke detaley shtangovykh nasosov // KHPI Mezhdunarodnaya nauchno-prakticheskaya konferentsiya magistrantov i aspirantov: materialy konf., 19-22 list. 2019 s. / pod red. Ê. Í. Sokol; Nat. tech. un-t "Kharkiv. politekh. in-t" [to v.]. - Kharkiv: NTU «KhPI», 2019. - p. 548. 3. Ananchenko V.N., Tsybriy I.K., Morgunov V.V. - Osobennosti izgotovleniya i kontrolya rez'by na trubakh neftyanogo sortamenta - Vestnik DGTU, 2009. Spets. vypusk. "Tekhnicheskiye nauki". 
Chast' I. pp. 48-55. 4. Knight W.A., Tobias S.A. Tensional vibrations and machine tool satiability. [Advances in machine tool decagon research / Proceedings of the 10t international NTDR conference]. Oxford, 1970. - pp. 299-323. 5. Astashev V.K., Korendyasev G. K. V modelyakh vozbuzhdeniya avtokolebaniy pri rezanii metallov. Vestnik nauchno-tekhnicheskogo razvitiya. Moscow. 2012. - № 5. pp. 19-25. 6. Vasil'kov D.V., Aleksandrov A.S., Golikova V.V. Sushchnost' avtokolebaniy v metallorezhushchiy stankakh. // Sistemnyy analiz i analitika, №1 (9) - St. Petersburg, 2019. 166 p., pp.16-22. 7. Novikov F.V., Kryuk A.G., Ryabenkov A.I., Ivanov I.Ye. Analiticheskoye opredeleniye amplitudy avtokolebaniy pri tochenii. Vestnik Natsional'nogo tekhnicheskogo universiteta «KhPI» Sbornik nauchnykh trudov. Seriya: "Innovatsionnyye tekhnologii i oborudovaniye obrabotki materialov v mashinostroyenii i metallurgii”. - Kharkiv: NTU «KhPI». - 2014. - № 5 (1048), pp. 156-161. 8. Korendyasev $K$. V fizicheskoy prirode effektov, lezhashchikh $\mathrm{v}$ osnove modeli vozbuzhdeniya avtokolebaniy pri rezanii Kashirina Vestnik nauchno-tekhnicheskogo razvitiya, №12 (148), pp. 17-23. Moscow: 2019. ISSN: 2070-6847, DOI: https://doi.org/10.18411/vntr2019-148-3. 9. Amosov I.S. Ostsillograficheskoye issledovaniye vibratsiy pri rezanii metallov. "Tochnost' mekhanicheskoy obrabotki i puti yeye povysheniya": Sbornyk nauchn. tr. - Moscow: Publ. Mashgiz, 1951. 10. Orgiyan A.A., Tvorishchuk I.M. Intensivnost' parametricheskikh rezonansov pri preryvistom rezanii. ISSN 2078-7499. "Sovremennyye tekhnologii v mashinostroyenii”, 2014, vyp. №9. pp. 124-138. 11. Chuangwen X., Jianming D., Yuzhen C., Huaiyuan L., Zhicheng S., Jing X. The relationships between cutting parameters, tool wear, cutting force and vibration. Advances in Mechanical Engineering. - 2018. - Vol. 10. - Iss. 1, pp. 1-14. 12. Shan'shin I.K., Shagniyev O.B., Burdakov S.F. Adaptivnoye podavleniye neustoychivykh regenerativnykh avtokolebaniy vyborom glubiny rezaniya. "Nedelya nauki" St. Petersburg: "Materialy nauchnoy konferentsii s mezhdunarodnym uchastiyem, 19-24 noyabrya 2018 g. Institut prikladnoy matematiki i mekhaniki". St. Petersburg. Publ: PolitekhPRESS, 2018. - pp. 338-341.

\title{
Ігор Яковенко, Юрій Василевський, Свгенія Басова, Харків, Україна, Мілан Едл, Плзень, Чеська Республіка
}

\section{ТЕХНОЛОГІЧНЕ ЗАБЕЗПЕЧЕННЯ ТОЧНОСТІ ФОРМИ ПРОФІЛЮ РІЗЬБИ ШТАНГОВИХ НАСОСІВ}

\begin{abstract}
Анотація. Розглянуто аспекти виготовлення різьблень, які використовуються в свердловинних штангових насосах. Описано технологічні дефекти спотворення бокових поверхонь профіля різьблення, щуо виникають в процесі обробки на верстатах з ЧПК, та встановлено фактори, які найбільш впливають на утворення цих дефектів. Проаналізовано вплив дефектів профілю на надійність різьбового з'єднання в процесі експлуатації итангових насосів, а також проаналізовано дослідження з питань динаміки ц̆ коливань верстатних систем. Завдяки виконаного аналізу створено і досліджено математичну модель реальної технологічної системи, яка використовується в процесі обробки різьбової поверхні. Встановлено основні технологічні фактори, які мають найбільший вплив на виникнення похибки форми різьбової поверхні. За допомогою програмного забезпечення для дослідження динамічних систем виконано необхідні розрахунки та розглянуто поведінка системи Верстат-Пристосування-Заготовка-Інструмент в процесі формування профілю різьби. На підставі аналізу отриманих результатів розроблена система керування параметрами технологічного прочесу обробки різьбової поверхні та сформульовані технологічні рімення, впровадження яких мало позитивний вплив на стабільність якості процесу обробки та на зменшення частоти появи розглянутого вище дефекту точності форми профілю різьблення та підвищило ефективність виробництва.
\end{abstract}

Ключові слова: різьбове з'єднання; профіль різьблення; технологічна система; режим різання; коливання; амплітуда; математичне моделювання. 